\title{
Progress in research on immunological mechanism of leprosy
}

\author{
Benson Kiprono Kosgei ${ }^{1}$, Luo Yun-Peng ${ }^{2}$ \\ ${ }^{1}$ International Education college, Jiangxi University of TCM, Nanchang, 330004, China, ${ }^{2}$ Department of Pathology \& Pathophysiology, \\ Chongqing Medical University, Chongqing,400016, China
}

Leprosy is a chronic infection acquired after getting exposed to Mycobacterium leprae (M.Leprae), especially via contact or through nasal secretions of the affected hosts. Ninety five percent of the entire population is naturally immune to leprosy due to the inherent natural immunity against the pathogen. The components of M.leprae include the lipoarabinomannam, the mycolyl-arabinogalactan-peptidoglycan complex, the protein-peptidoglycan complex, and muramyl dipeptide which are potent inducers of inflammatory mediators, especially TNF- $\alpha$. Immunologically and clinically leprosy is classified into the Tuberculoid pole, Borderline tuberculoid, Mid borderline, Borderline lepromatous and lepromatous pole. In the Tuberculoid pole, the naive CD 4 lymphocytes differentiate into either $T_{h} 1$ or $T_{h} 17$ cells. Th1 secretes IL-2, TNF- $\alpha$, IFN- $\gamma$, and Th17 secretes IL-17, IL- 21 and TNF- $\alpha$. In the Lepromatous pole, the naive CD 4 lymphocytes differentiate into Th2 cells, which secrete IL-1 $\beta$, IL-4, and IL-6 that promotes antibody formation. Knowing about the immune cells, mechanisms of their interaction and substances responsible in leprosy reactions can provide a potential way of enhancing the immune response to M.leprae especially in the Lepromatous pole or ways of preventing the nerve damage and skin lesions in leprosy.

Keywords: Lepromatous leprosy, $\mathrm{T}_{\mathrm{h}} 17$ and $\mathrm{T}_{\mathrm{h}} 1$ immune mechanism

\section{INTRODUCTION}

Leprosy is a chronic infection acquired by being exposed to M. leprae, an acid fast bacillus. M.leprae is a slow growing organism with a longer incubation period. Initially it could not be cultured in vitro ${ }^{1,2}$ because of its genetic composition which allows it to depend on the host energy metabolism for survival. Genetic studies reveal that it has less than $50 \%$ coding capacity and a lot of pseudogenes with the rest being responsible for its in vivo survival and pathogenesis in the host. ${ }^{3}$ The identification of the nine banded armadillos and M.leprae being able to infect the species has enabled the identification of the immune cells involved in the leprosy reactions with the development of appropriate drug combinations to improve on the health outcome. Since the introduction of the Multidrug Therapy (MDT) for leprosy, it's prevalence in the endemic regions has been reduced to less than 1000 cases per 10,000 population. Lepra reactions have been shown to occur before, during and after the MDT course for leprosy, worsening the nerve and skin lesions. Given that M. leprae has a predilection to the peripheral nerve Schwann cells, this leads to the severe nerve lesions, with consequent motor and sensory loss, muscle atrophy, and deformities, especially in Lepromatous leprosy cases. This occurs due to the exaggerated immune response to the Mycobacterium leprae. There is diverse immune responses towards M.leprae both the cell mediated and humoral mediated, with the cells involved being $\mathrm{CD} 4^{+} \mathrm{T}$ cells and antibodies respectively. The antibody response leads to more severe nerve and skin lesions with systemic manifestations. The histopathology of tissues appears multibacillary which makes these cases very contagious either through the skin contact or nasal secretions. This indicates the $\mathrm{T}_{\mathrm{h}} 2$ mediated immune reaction is not effective in combating M.leprae. Finding ways to shift the immune response from a $\mathrm{T}_{\mathrm{h}} 2$ to $\mathrm{T}_{\mathrm{h}} 1$ mediated will reduce the bacillary load in Lepromatous cases and prevent the systemic involvement of leprosy. The $\mathrm{T}_{\mathrm{h}} 17$ 
response appears to enhance the type 1 reaction. It offers a potential target into either enhancing the immune response in case of lepromatous pole or regulating the exaggerated response in some cases.

\section{MYCOBACTERIUM LEPRAE}

The components of the M.leprae includes: the lipoarabinomannan (a lipopolysaccharide-like component), the mycolyl-arabinogalactan-peptidoglycan complex, the protein-peptidoglycan complex, and muramyl dipeptide all of which are potent inducers of the inflammatory mediators, especially the TNF- $\alpha .{ }^{4}$

Due to its lipid content on the cell wall, M.leprae can leave persistent antigens on the nerves and skin which will continuously stimulate the host immune reactions, even after the completion of multiple drug therapy. ${ }^{5}$

\section{GENETIC DETERMINANTS: SUSCEPTIBILITY TO LEPROSY}

Ninety five percent of the entire population is naturally immune to leprosy, ${ }^{6}$ which is due to the inherent natural immunity against the M.leprae. Various genes regulating both innate and adaptive immune response influence the disease outcome. The TLRs, NOD2 \& MRC1 (mannone receptor type 1) are responsible for pattern recognition receptors and mycobacterial uptake, promoting autophagy, and the LTA4H regulates lipoxin A4 levels. The stimulation of these pathways regulates the cellular metabolism upon infection, and activates cytokine production through the NF-KB and the vitamin D- vitamin D receptor pathways. The PARK2 gene regulates the host cells apoptosis. The TNF, LTA \& IFNG genes triggers and maintain the formation of granulomas. The HLA gene in chromosome 6, IL-10 and the TNF/LTA axis, the IFNG/ IL-12 axis induces the differentiation of naive CD 4 lymphocytes. Single nucleotide polymorphism in these genes influences the immune response and subsequent susceptibility to M.leprae and its antigens. ${ }^{7-11}$

\section{MODES OF TRANSMISSION}

Leprosy is a communicable disease and can be transmitted from person to person via the respiratory droplets and skin contact with the infected people. M.leprae has been shown to be found in the nasal mucosa and skin, and this can be shed off and acquired by close contacts. ${ }^{12-17}$ However the Tuberculoid pole of leprosy is the least communicable of all the communicable diseases and the Lepromatous pole is the most contagious. Avoiding contact can lessen the chance of acquisition especially hosts with lepromatous leprosy.

\section{RIDLEY \& JOPLING CLASSIFICATION OF LEPROSY}

Mycobacterium leprae has been shown to be able to stimulate a wide range of host innate and adaptive immunity, both cell-mediated and humoral mediated response, with the predominance of the $\mathrm{CD}^{+}$lymphocytes and antibodies respectively. ${ }^{18}$

This has led to an immunological classification of leprosy into five forms: tuberculoid polar leprosy (T'T), borderline tuberculoid (BT), midborderline (BB), borderline lepromatous (BL), and lepromatous pole (LL) ${ }^{19-21}$ as shown in table below. Due to the difference in immune response at the two poles, biopsy samples shows the tuberculoid pole is paucibacillary and the lepromatous pole is multibacillary, fewer bacilli and more bacilli respectively. The skin lesions in the multibacillary form are less, usually localized and in the paucibacillary forms they are multiple and widespread. The leprosy reactions in the two poles occur regardless of viability of M.leprae. ${ }^{22}$

\section{MODIFIED RIDLEY \& JOPLING'S CLASSIFICATION}

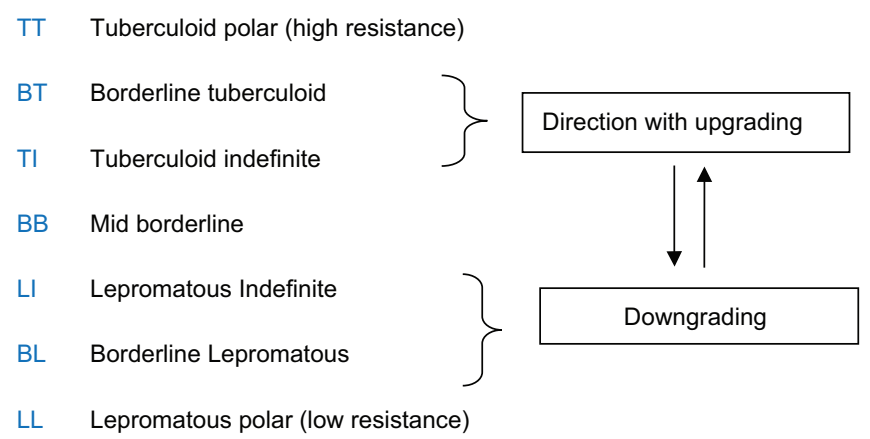

\section{IMMUNOLOGY: LEPRAE REACTIONS}

The tuberculoid pole of leprosy has a CD $4^{+}$lymphocyte mediated, delayed type hypersensitivity. ${ }^{17,23-26}$ The naive CD $4 \mathrm{~T}$ lymphocytes upon stimulation differentiate into either $\mathrm{T}_{\mathrm{h}} 1$ or $\mathrm{T}_{\mathrm{h}} 17 \mathrm{~T}$ lymphocytes depending on the cytokine environment. ${ }^{27}$

Type I reaction (reversal reaction)

$\mathrm{T}_{\mathrm{h}} 1$ secretes IL- 2 that leads to more differentiation of the naive CD 4 cells into $\mathrm{T}_{\mathrm{h}} 1$ cells and the IFN- $\gamma$, TNF- $\beta$ which signals for macrophage activation from the monocytes. ${ }^{25,26} \mathrm{~T}_{\mathrm{h}} 17$ has been implicated in the type I reaction to M.leprae. The Foxp3 staining has been observed, 
which is a transcription factor regulating the differentiation of $\mathrm{T}$ regulatory cell $\left(\mathrm{CD} 4^{+} \mathrm{CD} 25^{+}\right) .^{28}$

$\mathrm{T}$ regulatory cells are involved in down regulating the immune response to avoid exaggerated response including the $\mathrm{T}_{\mathrm{h}} 17$ mediated response which seems to play a role in the type I reaction to M.leprae. ${ }^{29-32} \mathrm{~T}_{\mathrm{h}} 17$ is stimulated from the naive CD 4 cells by IL-6, IL-21 and TGF- $\beta .33-43$

The mature $\mathrm{T}_{\mathrm{h}} 17$ then secretes IL-17, which is a proinflammatory cytokine. Also it secretes IL-21, showing that this cytokine has an autocrine function on $T_{h} 17 .{ }^{44}$ IL-23 are necessary for the expansion of the already differentiated $\mathrm{T}_{\mathrm{h}} 17$ cells and in maintaining IL-17 secretion. It achieves this by binding to the IL-23R on the surface of the $\mathrm{T}_{\mathrm{h}} 17$ cells. ${ }^{38,44-47} \mathrm{IL}-6, \mathrm{IL}-21$ stimulates the expression of IL-23R.$^{48}$ The IL-17, IL-21 then mediates inflammatory response against the pathogen. ${ }^{49}$ Mature $\mathrm{T}_{\mathrm{h}} 17$ cells have the ability to secrete TNF- $\alpha$, and also it can stimulate other immune cells to secrete the cytokine. ${ }^{50,51} \mathrm{~T}$ regulatory cells have been reported that they can be genetically reprogrammed. Inducible $T$ regulatory cells, in presence of TNF- $\alpha$, IL- 6 can be reprogrammed to $T_{h} 17$ phenotype. Naturally occurring $T$ regulatory cells can be stimulated to secrete IL-17 and to down regulate their Foxp3 expression in the presence of IL- 6, IL- 23 and IL- $1 .^{52-55}$ This can serve as a potential therapeutic target into enhancing the immune response to M.leprae, or suppressing the exaggerated leprosy reactions. Appropriate reprogramming factors should be sought for. The monocytes then cross the endothelium, become macrophages with a capacity to carry out phagocytosis. The phagocytosis by macrophages is mediated by complement receptors CR 1 (CD 35), CR 3 (CD 11b/CD 18), and CR 4(CD 11c/CD 18) and is regulated by protein kinases. ${ }^{56,57}$ This leads to granuloma formation, with differentiated macrophages, epithelioid and giant cells with a reduction in the bacillary load (paucibacillary).

The $T_{h} 1, T_{h} 17$ mediated response is effective against M.leprae. It's an upgrading immune response that leads to the tuberculoid pole. Due to the predilection of M.leprae to the extreme cool ends and in the nerve Schwann cells, the type I reaction leads to severe nerve damage, characterized by nerve thickening with lose of motor and/or sensory activity in the affected regions, edema and erythematous skin lesions. Systemic involvements are rare.

\section{Type II reaction (Erythema nodosumLeprosum)}

The type II reaction, erythema nodosumleprosum occurs in the lepromatous pole. It's a $\mathrm{T}_{h} 2$ mediated response with the involvement of the antibodies. ${ }^{5,58}$ Some studies have shown a ratio of $1: 2$ for $\mathrm{CD} 4^{+}$: $\mathrm{CD} 8^{+} \mathrm{T}$ lymphocytes. ${ }^{58}$ The cytokines involved include IL-1 $\beta$, IL-4, IL-6,and
TNF- $\alpha .{ }^{25,59-62}$ They signal for the synthesis of specific antibodies from the $\mathrm{B}$ lymphocytes which are specific to the epitopes on the M.leprae. Immune complexes are formed which are eliminated by the complement activation. ${ }^{63}$ The large amount of TNF- $\alpha$ observed has been linked to the chemotaxis of neutrophils into the inflammatory sites. ${ }^{64}$ The expression of the E-selectin leads to the attachment of the polymorphonuclear cells to the endothelial cells leading to diapedesis, and their infiltration into the infected tissue. The infiltration by neutrophils also leads to tissue damage due to the lysosomal enzymes that they secrete. The damage is especially in the peripheral nerves and the extremities, with loss of motor activities and/or sensation and multiple skin lesions characterized by erythema, edema with systemic manifestations of fever, arthralgia, weight loss, lymphadenopathy, anorexia, and edema. The type II reaction is not effective against $M$. leprae as biopsy samples of individuals with the lepromatous leprosy shows cells with multiple acid-fast bacilli implying they have a specific energy to M.leprae.

The leprosy reactions occur before, during and after completion of multidrug therapy. ${ }^{5}$ It's the main reason for the neuropathy and the skin deformation that befalls on the leprosy infected individuals. Intake of corticosteroids, emotional/physical stress, and pregnancy predisposes to these reactions. ${ }^{65}$ Individuals with HIV/AIDS have not shown a higher susceptibility to leprosy, even with the reduced $\mathrm{CD} 4^{+} \mathrm{T}$ cell count to100 cells $/ \mu \mathrm{L}$. However some studies have shown that leprosy reactions can occur in individuals co-infected with HIV after antiretroviral therapy.

\section{CONCLUSION}

The $\mathrm{T}_{\mathrm{h}} 17$ lymphocytes offer a new therapeutic potential into enhancing the immune response in the Lepromatous pole cases. The $T_{h} 1$ and $T_{h} 17$ response is more effective and this reduces on the nerve, skin lesions and the systemic effects of M.leprae infection. Upgrading the response will improve on the management of leprosy.

\section{ACKNOWLEDGEMENT}

Jiangxi university of TCM management for their encouragement and support. My colleagues at the university for their motivation.

\section{REFERENCES}

1. Rastogi N, Legrand E and Sola C. The Mycobacteria: An introduction to nomenclature and pathogenesis.OIE Revue Scientifique ET Technique 2001; 20(1):21-54. 
2. Gutierrez MC, Supply $P$ and Brosch R. Pathogenesis of mycobacteria. Genome dynamics 2009; 6:198-210.

3. Cole ST, Eiglmeier K, Parkhill J, James KD, Thomson NR, Wheeler PR, et al. Massive gene decay in the leprosy bacillus. Nature 2001; 409(6823):1007-1011.

4. Barnes PF, Chatterjee D, Brennan PJ, Rea TH and Modlin RL. Tumor necrosis factor production in patients with leprosy. Infection and Immunity 1992; 60 (4):1441-1446.

5. Cogen mail AL, Walker SL, Roberts $\mathrm{CH}$, Hagge DA, Neupane KD, Khadge $S$, et al. Human Beta- Defensin 3 is Up- regulated in cutaneous Leprosy Type 1 reactions. Plos Neglected Tropical Diseases 2012; 6(11):1869.

6. deMessias-Reason IJ, Kremsner PG and Kun JF. Functional haploypes that produce normal Ficolin-2 levels protect against clinical leprosy. J infect Dis 2009; 199(6):801-804.

7. Alcais A, Alter A, Antoni G, Orlavo M, Van Thuc N, Singh M, et al. Stepwise replication identifies a low-producing lymphotoxin- $\alpha$ allele as a major risk factor for early-onset leprosy. Nature Genetics 2007; 39 (4): 517-522.

8. Mira MT, Alcais A, di Pietrantonio T, Thuc NV, Phuong MC, Abel L, et al. Segregation of HLA/TNF region is linked to leprosy clinical spectrum in families displaying mixed leprosy subtypes. Genes and Immunity 2003; 4(1): 67-73.

9. Misch EA, Macdonald M, Ranjit C, Sapkota BR, Wells RD, Siddiqui MR, et al. Human TLR1 deficiency is associated with impaired mycobacterial signaling and protection from leprosy reversal reaction. PLoS Neglected Tropical Diseases 2008; 2(5): 231.

10. Cardoso CC, Pereira AC, Brito-De-Souza VN, Dias- Baptista IM, Maniero VC, Venturini J, et al. IFNG +874 T>A single nucleotide polymorphism is associated with leprosy among Brazilians. Human genetics 2010; 128(5):481-490.

11. Cardoso CC, Pereira AC, Caroline de Sales M and Moraes MO. Leprosy susceptibility: Genetic variations regulate innate and adaptive immunity, and disease outcome. Future Microbiol 2011; 6(5): 533-549.

12. Job CK, Jayakumar $\mathrm{J}$ and Aschoff $\mathrm{M}$. Large numbers of Mycobacterium leprae are discharged from the intact skin of lepromatous patients; A preliminary report. International Journal of Leprosy and Other Mycobacterial Diseases 1999; 67(2): 164-167.

13. Shepard CC. Acid-fast bacilli in nasal excretions in leprosy, and results of inoculation of mice. American Journal of Epidemiology 1960; 71(2): 147-157.

14. Pedley JC. The nasal mucus in leprosy. Leprosy Review 1973; 44(1): 33-35.

15. Davey TF and Rees RJW. The nasal discharge in leprosy: Clinical and bacteriological aspects. Leprosy review 1974; 45(2):121-134.

16. Rees RJW and McDougall AC. Airborne infection with Mycobacterium leprae in mice. Journal of Medical Microbiology 1977; 10(1):63- 68.

17. Chehl S, Job CK and Hastings RC. Transmission of leprosy in nude mice. American Journal of Tropical Medicine and Hygiene 1985; 34(6): 1161-1166.

18. Yamamura M, Uyemura K, Deans RJ, Weinberg K, Rea TH, Bloom BR, et al. Defining protective responses to pathogens: Cytokine profiles in leprosy lesions. Science 1991; 254(5029): 277-279.

19. Ridley DS and Jopling WH. Classification of leprosy according to immunity. A five- group system. International Journal of Leprosy and other Mycobacterial Diseases.1966; 34(3): 255-273.

20. WHO. Chemotherapy of leprosy for control programmes. World Health Organization Technical Report Series 1982;675:1-33.
21. Skinsnes OK. The immunopathologic spectrum of leprosy. Leprosy in theory and practice. John Wright \& sons Ltd, Bristol $1964 ; 152-182$.

22. Scollard DM, Adams LB, Gillis TP, Krahenbuhl JL, Truman RW and Williams DL. The continuing challenges of leprosy. Clin Microbiol 2006;19(2): 338-381.

23. Bjune G, Barneston RS, Ridley DS and Kronvall G. Lymphocyte transformation test in leprosy: Correlation of the response with inflammation of lesions. Clinical and Experimental Immunology 1976; 25 (1): 85-94.

24. Rea TH and Levan NE. Current concepts in the immunology of leprosy. Archives of Dermatology 1977; 113(3): 345- 352.

25. Young SK, Rayment N, Brickell PM, Katz DR, Vinayakumar S, Colston MJ, et al. Tumor necrosis factor-alpha (TNF- $\alpha$ ) synthesis is associated with the skin and peripheral nerve pathology of leprosy reversal reactions. Clinical and Experimental Immunology.1995; 99(2): 196-202.

26. Little D, Young SK, Coulthart A, Suneetha S and Lockwood DNJ. Immunohistochemical analysis of cellular infiltrate and gamma interferon, interleukin- 12, and inducible nitric oxide synthase expression in leprosy type 1 (reversal) reactions before and during prednisolone treatment. Infection and Immunity 2001; 69 (5) 3413 -3417.

27. Boniotto M, Jordan WJ, Eskdale J, Tossi A, Antcheva N, Crovella $\mathrm{S}$, et al. Human beta-defensin 2 induces a vigorous cytokine response in peripheral blood mononuclear cells. Antimicrob Agents Chemother 2006; 50(4): 1433-1441.

28. Lo CH, Lee SC, Wu PY, Pan WY, Su J, Cheng CW, et al. Antitumor and antimetastatic activity of IL-23. J Immunol 2003 171(2):600-607.

29. Gershon RK and Kondo K. Cell interactions in the induction of tolerance: The role of thymic lymphocytes. Immunology 1970; 18(50):723-737

30. Sakaguchi S, Sakaguchi N, Asano M, Itoh M and Toda M. Immunologic self-tolerance maintained by activated $\mathrm{T}$ cells expressing IL-2 receptor alpha-chains (CD25). Breakdown of a single mechanism of self-tolerance causes various autoimmune diseases. J Immunol 1995; 155(3):1151-1164.

31. Sakaguchi $S$, Yamaguchi $T$, Nomura $T$ and Ono M. Regulatory $T$ cells and immune tolerance. Cell 2008; 133(5):775-787.

32. Murphy TJ, Ni Choileain N, Zang Y, Mannick JA and Lederer JA. $\mathrm{CD} 4^{+} \mathrm{CD} 25^{+}$regulatory $\mathrm{T}$ cells control innate immune reactivity after injury. J Immunol 2005; 174(5):2957-2963.

33. Reiner SL. Development in motion: Helper $\mathrm{T}$ cells at work. Cell 2007; 129(1):33-36.

34. Mosmann TR, Cherwinski H, Bond MW, Giedlin MA and Coffman RL. Two types of murine helper T cell clone. Definition according to profiles of lymphokine activities and secreted proteins. J Immunol 1986; 136(7):2348-2357.

35. Bettelli E, Carrier Y, Gao W, Korn T, Strom TB, Oukka M, et al. Reciprocal developmental pathways for the generation of pathogenic effector TH17 and regulatory T cells. Nature 2006; 441(7090):235-238.

36. Mangan PR, Harrington LE, O'Quinn DB, Helms WS, Bullard DC, Elson CO, et al. Transforming growth factorbeta induces development of the Th17 lineage. Nature 2006; 441(7090):231-234.

37. Veldhoen M, Hocking RJ, Atkins CJ, Locksley RM and Stockinger B. TGF beta in the context of an inflammatory cytokine milieu supports de novo differentiation of IL-17producing T cells. Immunity 2006; 24(2):179-189.

38. Korn T, Bettelli E, Gao W, Awasthi A, Jager A, Strom TB, et al. IL-21 initiates an alternative pathway to induce proinflammatory $\mathrm{T}_{\mathrm{h}} 17$ cells. Nature $2007 ;$ 448(7152):484-487. 
39. Wilson NJ, Boniface $\mathrm{K}$, Chan JR, McKenzie BS, Blumenschein WM, Mattson JD, et al. Development, cytokine profile and function of human interleukin 17-producing helper $\mathrm{T}$ cells. Nat Immunol 2007; 8(9):950-957.

40. Ouyang W, Kolls JK and Zheng Y. The biological functions of T helper 17 cell effector cytokines in inflammation. Immunity 2008; 28(4):454-467.

41. Manel N, Unutmaz D and Littman DR. The differentiation of human Th17 cells requires transforming growth factor-beta and induction of the nuclear receptor RORYT. Nat Immunol 2008; 9(6):641-649.

42. Volpe E, Servant N, Zollinger R, Bogiatzi SI, Hupe P, Barillot $E$, et al. A critical function for transforming growth factorbeta, interleukin 23 and proinflammatory cytokines in driving and modulating human $\mathrm{T}(\mathrm{H})-17$ responses. NatImmunol 2008; 9(6):650-657

43. Wei G, Wei L, Zhu J, Zang C, Hu-Li J, Yao Z, et al. Global mapping of $\mathrm{H} 3 \mathrm{~K} 4 \mathrm{me} 3$ and $\mathrm{H} 3 \mathrm{~K} 27 \mathrm{me} 3$ reveals specificity and plasticity in lineage fate determination of differentiating CD4+ $T$ cells. Immunity 2009; 30(1):155-167.

44. Nurieva R, Yang XO, Martinez G, Zhang Y, Panopoulos AD, Ma L, et al. Essential autocrine regulation by IL-21 in the generation of inflammatory T cells. Nature 2007; 448(7152):480-483.

45. Veldhoen M, Hocking RJ, Atkins CJ, Locksley RM and Stockinger B. TGF beta in the context of an inflammatory cytokine milieu supports de novo differentiation of IL-17producing T cells. Immunity 2006; 24(2):179-189.

46. Cassan C, Piaggio E, Zappulla JP, Mars LT, Couturier N, Bucciarelli $F$, et al. Pertussis toxin reduces the number of splenic Foxp3+ regulatory T cells. J Immunol 2006; 177(3):1552-1560.

47. Langrish CL, Chen Y, Blumenschein WM, Mattson J, Basham B, Sedgwick JD, et al. IL-23 drives a pathogenic T cell population that induces autoimmune inflammation. J Exp Med 2005; 201(2):233-240.

48. Zhou L, Ivanov LL, Spolski R, Min R, Shenderov K, Egawa T, et al. IL-6 programs $\mathrm{TH}-17$ cell differentiation by promoting sequential engagement of the IL-21 and IL-23 pathways. Nat Immunol 2007; 8(9):967-974.

49. Ye $\mathrm{P}$, Rodriguez $\mathrm{FH}$, Kanaly $\mathrm{S}$, Stocking $\mathrm{KL}$, Schurr J, Schwarzenberger $P$, et al. Requirement of interleukin 17 receptor signaling for lung CXC chemokine and granulocyte colony-stimulating factor expression, neutrophil recruitment, and host defense. J Exp Med 2001; 194(4):519-527.

50. Jovanovic DV, Di Battista JA, Martel-Pelletier J, Jolicoeur FC, He Y, Zhang M, et al. IL-17 stimulates the production and expression of proinflammatory cytokines, ILbeta and TNF-alpha, by human macrophages. J Immunol 1998; 160(7):3513-3521.

51. Infante-Duarte $\mathrm{C}$, Horton $\mathrm{HF}$, Byrne $\mathrm{MC}$ and Kamradt T. Microbial lipopeptides induce the production of IL-17 in Th cells. J Immunol 2000; 165(11):6107-6115.

52. Xu L, Kitani A, Fuss I and Strober W. Cutting edge: Regulatory $T$ cells induce CD4+CD25-Foxp3- $T$ cells or are self-induced to become Th17 cells in the absence of exogenous TGF-beta. $J$ Immunol 2007; 178(11):6725-6729.

53. Yang XO, Nurieva R, Martinez GJ, Kang HS, Chung Y, Pappu BP, et al. Molecular antagonism and plasticity of regulatory and inflammatory T cell programs. Immunity 2008; 29(1):44-56.

54. Zhou L, Lopes JE, Chong MM, Ivanov II, Min R, Victora GD, et al. TGF-beta-induced Foxp3 inhibits $T_{h} 17$ cell differentiation by antagonizing ROR gammat function. Nature 2008; 453(7192):236-240.

55. Peng G, Guo Z, Kiniwa Y, Voo KS, Peng W, Fu T, et al. Tolllike receptor 8-mediated reversal of CD4+ regulatory $\mathrm{T}$ cell function. Science 2005; 309(5739):1380-1384.

56. Schlesinger LS and Horwitz MA. Phagocytosis of Mycobacterium leprae by human monocyte-derived macrophages is mediated by complement receptors CR1 (CD35), CR 3 (CD 11b/CD 18), and CR 4 (CD 11c/CD 18) and IFN-y activation inhibits complement receptor function and phagocytosis of this bacterium. Journal of Immunology 1991; 147(6):1983-1994.

57. Prabhakaran K, Harris EB and Randhawa B. Regulation by protein kinase of phagocytosis of Mycobacterium leprae by macrophages. Journal of Medical Microbiology 2000; 49(4): 339-342.

58. Van Voorhis WC, Kaplan G and Sarno EN. The cutaneous infiltrates of leprosy. Cellular characteristics and the predominant T-cell phenotypes. New England Journal of Medicine 1982; 307(26): 1593-1597.

59. Sarno EN, Grau GE, Vieira LMM and Nery JA. Serum levels of tumor necrosis factor-alpha and interleukin-1 $\beta$ during leprosy reactional states. Clinical and Experimental Immunology 1991; 84(1): 103-108.

60. Sreenivasan P, Misra RS, Wilfred D and Nath I. Lepromatous leprosy patients show $\mathrm{T}$ helper 1-like cytokine profile with differential expression of interleukin- 10 during type 1 and 2 reactions. Immunology 1998; 95(4): 529-536.

61. Nath I, Vemuri N, Reddi AL, Jain S, Brooks P, Colston MJ, et al.The effect of antigen presenting cells on the cytokine profiles of stable and reaction allepromatous leprosy patients. Immunology Letters 2000; 75(1): 69-76.

62. Moraes MO, Sampaio EP, Nery JAC, Saraiva BC, Alvarenga FBF and Sarno EN. Sequential erythema nodosumleprosum and reversal reaction with similar lesional cytokine mRNA patterns in a borderline leprosy patient. British Journal of Dermatology 2001; 144(1): 175- 181.

63. Bjorvatn B, Barnetson RS and Kronwall G. Immune complexes and complement hypercatabolism in patients with leprosy. Clinical and Experimental Immunology 1976; 26(3):388- 396.

64. Kahawita IP and Lockwood DNJ. Towards understanding the pathology of erythema nodosum leprosum. Transactions of the Royal Society of Tropical Medicine and Hygiene 2008; 102(4): 329- 337.

65. Lienhardt $\mathrm{C}$ and Fine PEM. Type 1 reaction, neuritis and disability in leprosy: What is the current epidemiological situation? Leprosy Review 1994; 65(1): 9- 33. 